\title{
Pandemic Management Systems and Migration
}

DOI: https://doi.org/10.11567/met.36.2.4

UDK: 314.15:616.9(091)

Pregledni rad

Primljeno: 2.1.2021. Prihvaćeno: 24.2.2021.

Margareta Gregurović

Institute for Migration and Ethnic Studies, Zagreb

margareta.gregurovic@imin.hr

Snježana Gregurović

Institute for Migration and Ethnic Studies, Zagreb

snjezana.gregurovic@imin.hr

Josip Kumpes

Institute for Migration and Ethnic Studies, Zagreb

josip.kumpes@imin.hr

Simona Kuti

Institute for Migration and Ethnic Studies, Zagreb

simona.kuti@imin.hr

Sanja Lazanin

Institute for Migration and Ethnic Studies, Zagreb

sanja.lazanin@imin.hr

Dubravka Mlinarić

Institute for Migration and Ethnic Studies, Zagreb

dubravka.mlinaric@imin.hr

\section{SUMMARY}

Fast development and transmission of disease poses a health threat for a larger population and affects the functioning of almost all social systems, both within and outside nation-state borders, thus also affecting the possibilities of free migration and movement. The main aim of this article is to discuss the principal mechanisms of disease control in relation to migration in various socio-historical contexts. It identifies and compares historical patterns and contemporary measures of preventive control systems while considering the wider social context and migrants' specific position. This paper combines the historical insights into various administrative and political systems in Europe and Croatia that have sought adequate measures to prevent the spread of infectious diseases with the current state of the affair in the fight against the COVID-19 pandemic. As part of the regulation and management of the 
contemporary COVID-19 pandemic, restrictions have been introduced on cross-border movement and travel. Those restrictions and quarantine measures have abruptly halted not only international but also migration within the borders of nation-states, especially during the first wave of the pandemic in spring 2020. Emphasis has been placed on the effects of the COVID-19 pandemic on labour and forced migration, as well as on the trends in public attitudes on immigrants affected by pandemic management mechanisms.

KEY WORDS: pandemic, migration, COVID-19, pandemic management, xenophobia

\section{INTRODUCTION}

The COVID-19 pandemic, like many pandemics before it, poses a health threat and affects the functioning of almost all social systems, both within and outside nation-state borders. ${ }^{1}$ Preventing the further transmission of the pandemic has particularly affected the spatial mobility of the population and migration. Restrictions on cross-border movement and travel and the introduction of quarantine measures have abruptly halted not only international but also migration within the borders of nation-states, especially during the first wave of the pandemic in spring 2020. Since the onset of the pandemic, the most severe restrictions on movement have been directed at older people, with constraints and age limits $(60+, 65+, 70+$, etc.) changing from country to country. Further on, various social groups are not equally affected by the disease (regardless of their age), migrants being among the ones that are at a greater risk. For example, inadequate accommodation and limited access to the sanitary system and healthcare institutions make irregular and forced migrants in refugee camps particularly vulnerable.

Building on rich archival materials on previous pandemics and contemporary data on the COVID-19 pandemic, the main aim of this article is to discuss the relationship between principal mechanisms of disease control and migration in various socio-historical contexts. For that purpose, historical patterns and contemporary measures of preventive control systems are being identified and compared, taking into account the wider social context and migrants' specific position. It is important to note that restriction of movement to combat and control epidemic diseases was introduced in various political and administrative systems in history, as evidenced by a

1 The first, more extensive version of this paper, "Pandemic and Migration", was prepared as an expert paper during the first wave of the COVID-19 pandemic in May 2020 and is available on the website of the Institute for Migration and Ethnic Studies, Zagreb. 
series of examples from ancient times and early modern states to the 20th century. The measures that were introduced to prevent disease outbreaks impacted all levels of the affected community or communities. Among others, these mechanisms and measures were, directly and indirectly, related to the implemented national migration policies and (un)favourable public attitudes, posing challenges to people whose life is determined by movement. Using the social history approach (Conrad, 2001: 14299), the paper unites the subdiscipline of historical sciences in the analysis of past experiences and dealing with various pandemics with the contemporary context of the COVID-19 pandemic in an "interdisciplinary alliance" between history and sociology (Conrad, 2001: 14302). The Croatian context has been the main focus of the analyses whenever possible.

\section{Sources and approach}

Within the historical perspective, the authors used a comparative qualitative analysis of various archival sources of Venetian and Austrian provenance. The goal was to identify historical patterns of establishing and implementing preventive control systems that had limited the spread of infectious diseases. Complex and multidimensional problems caused by infective disease influenced society as a whole. Therefore, the analysis of historical sources aimed to provide an overview of medical measures with a specific focus on the prevention of human health actions and the creation of a public healthcare system in the Croatian lands. Besides that, the focus was on the comparison of organised anti-epidemic responses of several neighbouring power states, which ruled over various parts of Croatian lands from the Middle Ages on. The analysis also focused on the socio-economic consequences of implemented anti-epidemic measures, namely their impact on spatial mobility and migration.

The analysis of effects of the contemporary COVID-19 pandemic on migration was based on the desk research of collected scholarly studies and scholars' published commentaries on the subject, media sources, documents issued by institutions dealing with the pandemic and various aspects of migration (i.e., World Health Organization - WHO, International Organization for Migration - IOM, etc.) in the Croatian, international or other national contexts. Since COVID-19 is relatively under-researched in the context of migration, the paper offers a descriptive review of the collected materials, focusing on the social effects of the pandemic on migrants. 


\section{PANDEMICS AND MIGRATION: A HISTORICAL PERSPECTIVE}

The epidemiological and socio-economic constraints on the freedom of movement, which are currently being introduced around the globe to prevent the spread of the SARS-CoV-2 virus, are not unprecedented. The history of Europe and Croatia saw various administrative and political systems seek adequate measures to prevent the spread of infectious diseases as that was the only known way of coping with this grave demographic, economic and public health issue. The perspective of social history as an approach to studying anti-epidemic measures that were used in the past to protect populations and their economies has several advantages. Besides drawing interesting parallels with the present situation caused by the COVID-19 pandemic, it enables insight into various aspects of the complex relationship between diseases, public-health measures, and the mobility of people and goods.

The relationship between health and disease on the territory of Croatian historical lands partly resulted from severe devastation and suffering during and after the Ottoman wars. Hunger and inability to procure food were common in such circumstances. Infectious diseases affected the population exhausted by poverty, indirectly disrupting economic production through demographic devastation. The prevalence of diseases depended on several factors, such as climate, physical properties of the landscape, degree of socio-economic development (from access to water to transport infrastructure), etc. The transmission of infectious diseases was instigated by various types of mobility, from pilgrimage trips, wars and army troop movements, to mercantile activities. Apart from the plague, some of the most common diseases that afflicted the Mediterranean and Europe, including the eastern Adriatic coast and its hinterland, were smallpox, cholera, diphtheria, epidemic typhus, dysentery, tuberculosis, gout, malaria and many others.

Migration and migration policies were a focus of the interest of early modern European states. When deciding on these policies, authorities leaned on the prevailing economic doctrines of the time. Despite their differences in understanding sources of economic power, those doctrines emphasised the importance of population issues and demographic strength (Swann, 2000: 24). To increase their demographic potential, states typically resorted to migration as a means for securing the labour force needed for the demographic recovery of devastated regions. Paradoxically, migrations had a double effect: they accelerated the spread of diseases in uncontrolled conditions, and they worked as a mechanism of economic recovery in the aftermaths of huge epidemics. For governments, either central or local, it was decisive to 
gain control over the situation by implementing specific policy measures especially those related to migration, demographics and the economy. As it turned out (and as verified by historical records), medical and public-health decisions made on this assumption contributed to the economic advancement of the regions of today's Croatia.

\section{Plague epidemics, migration and the introduction of public health protection measures}

In historical sources, plague has been the best-documented disease since ancient times (Glesinger, 1954; Grmek, 1989; Buklijaš, 2002; Ravančić, 2010). The circulation of epidemics in the population coincided with the reproductive cycle of rats and fleas, spreaders of the bubonic form of the disease. When an epidemic broke out among animals, fleas would move from animals to humans in search of food, similar to the SARS-CoV-2 virus transfer. The disease mostly killed young and active members of the population, striking densely populated Europe and Asia most severely. The plague epidemic indirectly prompted, among other things, the migration of Slavs to new areas, but also the spread of Islam to uninfected semi-desert areas. From 1300 to 1450, Europe lost a third of its total population due to the plague epidemics, $60 \%$ of the total loss being in northern Europe (Livi Bacci, 2000: 83). During the 15th century, as many as twenty different waves of plague infections struck Dalmatian towns (Kolanović, 1995: 31).

Since the cause and cure were unknown, limiting the transmission of the disease was reduced to the public health measure of preventing physical contact between healthy and infected populations. Local communities regulated the issue of institutionalised charitable and medical care for the needy and marginal members of society, not only the sick but also the poor, the abandoned, and the elderly.

Venetian institutions on the eastern Adriatic coast sought to prevent the depletion of taxpayers, as the disease threatened their productive and fiscal capacity. The most efficient preventive measure to restrain diseases was mobility limitation, which led to the devastation of the economy reflected in the decrease or even shutdown of mercantile activities. ${ }^{2}$ Therefore, the

\footnotetext{
Some economic outcomes of the plague were the decrease in mercantile activities, agricultural damages and uncultivated lands, as well as the shortage of man-labour and social conflicts. The influence of the plague on social and economic changes has varied throughout history among various European regions, depending on the scope of disease and variations of wealth distribution due to significant demographic losses (Klueting, 2007: 39).
} 
administration tended to balance between medical and economic interests by carefully chosen public health policies. Led by the Sanitary Magistrate, as the highest healthcare authority, and local sanitary colleges, Venice implemented measures to prevent the introduction and transmission of infectious diseases through information, prevention, and repression (Peričić, 1974: 286). They controlled the disease through public health visitations, the publication of instructions, regulations, and manuals, the issuance of medical certificates, the opening of lazarettos, and, ultimately, the prohibition of movement for persons from unsafe areas. The 15th century saw the introduction of obligatory medical certificates for the free movement of goods and passengers (teskere or pattente nette, sospette or libre). ${ }^{3}$ They stated the holder's health state, and suspicious passengers had to be isolated (Kečkemet, 1975: 380-385).

Until the end of the 19th century, a universal antidote for the treatment of plague prescribed by physicians was the consumption of acidic foods, steaming (fumigation) of the body and objects with sulphur fumes, and bathing in vinegar, essential oils, and the sea (Božić-Bužančić, 1990: 248-254; Tartalja, 1979: 435-446). The plague resulted in severe socio-economic devastation but had equally far-reaching consequences for human behaviour and the understanding of the world. In a collective, fear-motivated attempt to explain the emergence of the disease, society most often blamed those different from the majority community, either travellers and foreigners or various marginalised groups, from denominations (e.g., Jews or Muslims) to the sick (e.g., lepers). Jews were prosecuted and murdered across various areas of western Europe during the great plague outbreak in 1348, all under the suspicion that they had poisoned the water sources and caused the disease (Delumeau, 1987, I: 155, 178; Klueting, 2007: 39-40).

Initially, there was a practice in the Mediterranean, supported by the medical profession, of letting nature take its course and protecting the healthy members of the community by walling in the sick and burning their hous-

3 A traveller with a pattente libre or the warranty of merchandise safety could easily enter the town. A neutral document (pattente nette) proved the traveller (merchant) had not visited an infected area within the previous thirty days. Highly suspicious was a person who obtained a pattente sospetta, coming from an area with some plague indications and traces. In that case, a preventive quarantine of ten days was obligatory. The worst certificate was the patente brutte, indicating proven infection in the place of departure. These travellers and their merchandise were subjected to strict quarantine procedures of inspection, ventilation, disinfection, and fumigation. The appointed offices for issuing the above-mentioned travelling certificates in the city of Dubrovnik were Rector et Consiliarij Republicae Ragusinae (HR-DAZD-386 Zbirka tiskovina /Stampata, box 86, No. 1, year 1746). 
es. ${ }^{4}$ Over time, however, an opposite method of protection developed, and that is the quarantine system. The great plague epidemic of the 14 th century resulted in the introduction of a public health innovation: preventive separation of potentially infected people and goods to preserve economic activities such as trade and maritime transport (Delumeau, 1987, I: 135). Sources record that Dubrovnik was the first state to introduce such a humanely acceptable system in 1377. It was based on the rational, empirical experience of noble merchants of Dubrovnik, fearing the spread of the pesta. It included forty-day isolation of passengers and their belongings in secluded locations. The mainland location of quarantine premises was at the eastern entrance to the city (the lazarettos). Those who came by sea were quarantined on the islands facing the city (Mrkan, Supetar, Bobara, and Mljet) (Buklijaš, 2002: 92). While, initially, merchants stayed under the open sky, over time, the system developed into an institution with elements of legal regulation, mandatory buildings and warehouses, and from 1426, with trained staff.

While Dubrovnik independently introduced and codified public health regulations (from the Green Book of 1377 to the Dubrovnik Republic Ordinance on Maritime Navigation of 1745), operating with the help of a system of city officials, the coastal cities of Venetian Dalmatia depended on the financial resources provided by Venice. The Venetian functional land quarantine system required a series of fortified containment control points that were to prevent the transmission of the disease along the long land border with the Ottoman Empire. Entrances to seaports were easier to control, although ports were areas of intensive trade in raw materials from the Dalmatian and Bosnian hinterlands and luxury goods from western European ports.

The quarantine system of control measures was strictly codified and organised. However, from time to time, attempts to bypass these rules were recorded, mostly by worried merchants who had endeavoured to decrease their economic losses (ZKZ, Ms. No. 26401, 21 R 658: 6). The articulation of definite legal penalties for those violators of law signified that the number of cases of bypassing and violating public health regulations was not minor. Those penalties included both sides involved: users of the quarantine system, as well as members of the staff involved in the implementation of quar-

4 Such a practice, widely used in Milan or Venice, was also used on the eastern Adriatic coast. During the plague in Posedarje and Vinjerac in 1650, count Jure Posedarski received the order issued by the general governor Foscolo to burn down all infected houses (HRDAZD-1(SGP), Leonardo Foscolo, book I, 550). 
antine public health control (HR-DAZD-1, Angelo Diedo, box 210: 48a). It became obvious very soon that quarantine measures of slowing down and postponing mercantile activity resulted in a state fiscal failure. Besides, medical preventive measures slowed down the functionality of public services. As a sort of a compromise, all those system deficiencies forced the local authorities to speed up the processes of traveller control (HR-DAZD-386 Zbirka tiskovina/Stampata, box 33, No. 6, year 1797).

The battle against epidemics and their devastating effects on the demographic composition and the economy of specific regions prompted early modern states to systematically develop public healthcare systems (Snowden, 2019: 69; Thießen, 2015: 16). The beginning of systematic healthcare in the Croatian lands under the Habsburg rule coincided with the establishment of the Sanitary Cordon in the area of the Croatian-Slavonian Military Frontier. One of the longest-lasting and most extensive anti-epidemic systems in Europe during the 18th and 19th centuries stretched from the Adriatic to the Carpathians, for a total length of 1900 kilometres.

The Habsburg anti-epidemic system on the border, with the Ottoman Empire on the one side and the Venetian estates in Dalmatia on the other, was formed gradually by the adoption of imperial provisions and legal acts. Prominent among the latter were the Patent of Charles VI of 1728, which established a permanent sanitary cordon on the eastern borders of the Habsburg Monarchy (Horbec, 2015: 90; Skenderović, 2015: 315-316), and the General Health Regulations (Sanitäts- und Kontumazordnung) (Horbec, 2015: 89-91) of 1770. Over the subsequent century, amendments to and adaptations of the regulations were made according to public health needs.

As a long-standing anti-epidemic system, the sanitary cordon served several functions; providing permanent cordon guards, collecting information on the epidemic in the Ottoman area and establishing permanent crossings for passengers and goods, the so-called containment stations (kontumaci). Located on the main roads along the border, they served as quarantines for the control of traffic and separation of potentially infected persons and goods. Quarantine was mandatory for both people and commodities. The latter were decontaminated depending on the type - washed under running water, fumigated with incense, ventilated, or disinfected by hot air (Taube, 2012: 133; Vaniček, 1875, I: 405-408; Horbec, 2015: 92-114).

The mandatory quarantine system significantly slowed down cross-border mobility with the Ottoman Empire. To fully appreciate the importance of 
this impediment, one has to bear in mind the intensity of both the trade in goods between the two empires and migrations from the Ottoman-controlled territories to those under Habsburg rule, especially in the post-war period. Since the fluidity of transport flows was vital for trade connections, equally in those days as today, the merchants sought ways to bypass the obligatory quarantine as an obstacle to free trade. One way to do this was to leave the exported merchandise in a containment station, which would then be picked up by a business partner on the Habsburg side of the border (Horbec, 2015: 115). All passengers coming from the Ottoman Empire, regardless of their social status, ethnicity or religion, had to provide travel documents and were subjected to the obligatory quarantine, after which they received a sanitary certificate (Engel, 2003: 390). The same applied to imported merchandise - artefacts and animals - which, following disinfection and quarantine, were provided with a certificate (Sanitäts-Zertifikat) enabling further transport and trade throughout the Monarchy (Taube, 2012: 133; Horbec, 2015: 111-112). Quarantine was obligatory for all migrants who intended to move from the Ottoman territory to the Habsburg territory (Vaniček, 1875, III: 334). ${ }^{5}$ Since sanitary regulations were being constantly violated, the so-called Patent on Containment Stations was adopted in 1766 (Horbec, 2015: 117), imposing criminal liability on officials in charge of antiepidemic measures, as well as individuals caught in illegal border-crossing with an intention of avoiding quarantine.

\section{Towards contemporary public-health measures}

Although plague almost disappeared from Europe during the 18th century, the areas closer to the Ottoman Empire saw occasional outbreaks of this disease in the first half of the 19th century. In the times when plague receded, other diseases like smallpox or cholera took its place, which prompt-

5 Regarding the number of people immigrating from the Ottoman to the Habsburg territories during the 18th century, it is hardly surprising that the correspondence between Habsburg officials in Vienna and various institutions in Slavonia contains details on immigration and border-crossing regulations. For instance, a document of 1786 mentions the immigration of families from the Ottoman territories to the Slavonian Military Frontier with the purpose of demographic recovery of this area. The document also reveals which categories were not eligible for settlement, such as the elderly or disabled persons. Besides, it contains detailed instructions to the kontumacs in Brod and Zemun as to how to treat immigrants from areas under Ottoman control (HR-HDA-430-SGK, Opći spisi, box 24, 1786-66-424). In 1787, a larger number of Serbian families determined to settle in Syrmia (Petrovaradin Regiment) had to undergo a 10-day quarantine at the border crossing before being directed to the destination of their settlement (HR-HDA-430-SGK, Opći spisi, box 26, 1787-55-250). 
ed authorities to introduce new anti-epidemic measures during the 18th and 19th centuries. While the institution of quarantine was being gradually abandoned, preventive vaccination, ${ }^{6}$ disinfection and treatment of diseases gained ground. Lists of vaccinated children from both the civil and the military parts of Slavonia testify to the importance of vaccination in Habsburgcontrolled territories in the 19th century. ${ }^{7}$

The history of the 20th century recorded two major European and global epidemics. The end of World War I saw an outbreak of a flu pandemic called "Spanish fever" or "Spanish flu", which killed an estimated fifty million people in several waves from 1918 to 1920 (Snowden, 2019: 84). Smallpox (variola vera) was another infectious disease with a high mortality rate, whose last European epidemic was recorded in Yugoslavia in the 1970s. Besides vaccination, the prohibition of leaving the place of residence and reducing the mobility of the population were the main measures to prevent the spread of the infection.

Each public health measure for the prevention of epidemics introduced from the early Middle Ages up to the present affected even the small, isolated communities, let alone large, complex, and highly interconnected economic systems.

This is why those in charge of the disease control system were eager to find a balance between the demographic and public health interests - primarily, preventing the spread of a disease on the one hand and the economic sustainability of such a system on the other. Nevertheless, there were always individuals, either among those in charge of introducing and implementing the measures or those affected by them, who tried to sidestep the stipulated regulations for various reasons. To prevent such misconduct, the authorities emphasised the importance of collective action aimed at combating epidemics and the need for mobility restrictions imposed on people and goods until a normal public health situation could be restored.

6 Edward Jenner, an 18th-century English physician, proposed a cure for smallpox (variola vera maior) by injecting a small number of pathogens into a healthy organism to attain immunity. The procedure was called vaccination (Snowden, 2019: 107). To promote vaccination as a new anti-epidemic method some rulers and royal family members, like the Habsburg Empress Maria Theresia, Russian Empress Katarina II, or the Princess of Wales, tried to set an example for the whole populace.

7 Children vaccination protocols of the Vinkovci Company from 1816 to 1820 available in HR-HDA-445-BGP, Satnija u Vinkovcima, book 233, 1816 - 1830. Children vaccination lists for all districts of the Virovitica County for the year 1810 available in HR-HDA-33VŽ, Spisi, box 305, No. 1337. 


\section{COVID-19 PANDEMIC AND MIGRATION}

The end of 2019 and the beginning of 2020 marked the start of a new, fastspreading disease caused by the SARS-CoV-2 virus and affecting human life on a global scale. Like previous pandemics, COVID-19 induced changes at all societal levels, from the macro-level management of public health issues to individual-level prescribed measures of social conduct. Among other spheres of social life, the movement of people has been severely impacted, especially during the first wave of the pandemic, in spring 2020. This section describes migration regulations within the pandemic management and their effects on a possible shift in the public perception of immigrants, taking into account the specificities of labour and forced migration. The Croatian context is emphasised whenever possible.

\section{COVID-19 and labour migration}

The closure of the state borders has shown how much today's global economy, but also individual national economies, depend on migration, i.e., on the spatial mobility of the labour force. According to the UN Department of Economic and Social Affairs (UN DESA) data for 2019, labour migrants make up two-thirds of the nearly 272 million international migrants worldwide (IOM, 2020a). By sending remittances and acquiring labour skills and knowledge, migrant workers contribute to the economic growth and development of not only the receiving countries but also the countries of origin. A significant number of activities such as healthcare, transportation, construction, agriculture, service provision, and food processing depend on the foreign labour force. Since one of the most recurring (inter)national recommendations to "work from home" is not possible in these sectors, workers are at a greater risk of contracting coronavirus. However, migrant workers in these sectors are often in a more unfavourable position compared to domestic workers, given their fixed-term contracts, irregular employment, lower wages, and inadequate social security (OECD/ILO, 2018).

In high-income countries, labour migrants make up $68 \%$ of the total number of international migrants. Most migrant workers $(60.8 \%)$ are in North America (23\%) and northern, southern, and western Europe (23.9\%) (ILO, 2018). Despite the unquestionable significance of migrant labour in the so-called essential activities, this category is affected by lay-offs and job losses due to the adverse effects of the pandemic on the economy (Fasani and Mazza, 2021). Migrant workers are in a vulnerable position due to the 
health and job impacts of the COVID-19 outbreak. Several studies have investigated the vulnerability of migrant workers to the effects of the coronavirus pandemic (Borjas and Cassidy, 2020; Fasani and Mazza, 2020; Gelatt, 2020; Paul, 2020). Inadequate conditions under which some of them live and work make them particularly susceptible to various infections, including the new coronavirus. ${ }^{8}$ The availability of adequate healthcare and social services to all workers, including migrants without a regulated employment relationship, is a vital factor in preventing the transmission of the disease.

Many of the barriers migrants face in accessing appropriate healthcare arise from financial obstacles, lack of healthcare entitlements and fear of deportation (WHO, 2020). Besides, according to the WHO ApartTogether survey, one out of six non-documented migrants (18.6\%) would not seek medical care for COVID symptoms, as opposed to respondents who are citizens $(5.9 \%)$ or regular migrants $(4.1 \%)$ (WHO, 2020).

Of the fifteen countries most affected by the first wave of the COVID-19 pandemic, in at least ten of them (the USA, Spain, Italy, Germany, France, the United Kingdom, Belgium, the Netherlands, Canada, and Switzerland), the healthcare sector depends on workers born abroad. In 2016, most foreign physicians in the USA and the United Kingdom had been educated in India and Pakistan. ${ }^{9}$ Most highly developed countries have been facing a shortage of healthcare workers for many years, and the COVID-19 pandemic has exacerbated the situation. The COVID-19 pandemic has also drawn attention to the role of migrant labour in the global economy and the problems that some economic branches will face if the movement of migrants becomes disabled. The agricultural sector, which employs a significant number of migrant workers, was especially affected, threatening to jeopardise global food supply chains. But due to restrictions on movement, bans on gatherings, and the closure of borders, other migrant-employing sectors, such as tourism, hospitality, hotel industry, and the entertainment industry, have also been heavily affected by the epidemic.

8 See: https://migrationnetwork.un.org/statements/covid-19-does-not-discriminate-norshould-our-response. Following the easing of restrictive measures in Germany, the new hotspots for coronavirus infection are slaughterhouses and meat processing factories, which mainly employ workers from Romania. The cause of these hotspots is not a lack of sanitation in the factories but inadequate sanitary conditions in which these workers live. Since they are housed in mass dormitories and former barracks, it is difficult for them to protect themselves from infection (https://www.dw.com/hr/njema\%C4\%8Dke-klaonicerasadnici-zaraze/a-53384461).

9 See: https://migrationdataportal.org/themes/migration-data-relevant-covid-19-pandemic. 
The new regime of limiting spatial mobility during the first wave of the COVID-19 pandemic especially jeopardised commuters or daily travellers (often mistakenly called daily migrants), who cross national borders for the day-to-day conduct of job-related activities. ${ }^{10}$ Therefore, they depend on the movement restrictions of not only one state (or regional self-government) but also other, most often neighbouring states. ${ }^{11}$ The introduction of stricter border controls and (self-)isolation rules for migrants, as well as general restrictions on spatial mobility to prevent the transmission of COVID-19, has restrained these workers from carrying out their daily job activities, with serious financial consequences for their families.

Upon introduction of the coronavirus prevention and protection measures in March 2020, the Croatian media highlighted the example of workers from Karlovac County who were prevented from the daily commute to the Slovenian Bela Krajina since that part of Slovenia was declared an area of a particularly high risk of coronavirus transmission. According to the county prefect, several hundred Croatian citizens had to choose between going to work and staying in Slovenia for the next two weeks or returning to Croatia after work and self-isolating for the following fourteen days. ${ }^{12} \mathrm{~A}$ few days later, the entire territory of the Republic of Slovenia was declared a risk area, so the same measures affected other workers travelling daily from Croatia to Slovenia.

The example of Croatia and Slovenia is neither an isolated one nor the most significant in Europe. The control of cross-border movement between, for example, Poland and Germany, has had even more pronounced socio-economic consequences during the first wave of COVID-19 pandemic given that, according to Eurostat data for 2018, around 125,000 Polish citizens travel to work in (eastern) Germany every day. ${ }^{13}$

10 This term refers to the daily commute over a relatively large distance between places of permanent or occasional residence, either for employment or other reasons. Since such cases imply no change in the place of residence, scholars mostly single them out from the category of migration and study them within the broader category of spatial mobility (Heršak, 1998; Bell and Ward, 2000).

11 Even though there are cases of long-distance cross-border commuting to non-neighbouring countries (using air transport), most empirically documented cases refer to the border regions of two nation-states (e.g. Wiesböck et al., 2016).

12 See: https://www.tportal.hr/vijesti/clanak/od-petka-obustava-dnevne-migracije-radnikaiz-hrvatske-u-belu-krajinu-20200312.

13 See: https://ec.europa.eu/eurostat/cache/digpub/eumove/bloc-2c.html?lang=en. Most of them (around 30\%) are men employed in the construction sector, but there are also workers in the food sector and medical personnel. 
Balancing between public health risks and economic pressures, the European Commission allowed the European countries to transport medicines, protective equipment, and other medical supplies, as well as to operate freight services crucial for the functioning of the EU's internal market. But the so-called non-compulsory travel, return and resettlement procedures for asylum seekers or asylees, as well as free movement of workers, were halted. However, the Commission issued guidelines to facilitate the crossing of borders by essential workers (healthcare workers, caregivers, food producers, and seasonal workers) employed in essential industries. ${ }^{14}$

Although the European Commission had recommended that the member states introduce border control without preventing the movement of essential workers, Poland failed to adapt the (newly introduced) national rules to EU recommendations. This created a labour shortage in the German food sector and healthcare and lead to economic consequences for Polish citizens, many of whom had to choose between losing their jobs and moving to Germany. ${ }^{15}$ Therefore, protests by several hundred Polish workers in the border areas of both Poland and Germany during the first wave of the pandemic were not a surprise. ${ }^{16}$

On the other hand, some states decided to open their labour markets to foreign workers despite the pandemic. Already in early April 2020, to save agricultural production, Germany envisaged the easing of strict border measures and the "import" of approximately 80,000 seasonal workers, mainly from Poland, Ukraine, Romania, and Hungary, for picking seasonal fruits and vegetables. ${ }^{17}$ In many cases, the COVID-19 pandemic caused labour shortages in the healthcare sector, and the need to "import" required foreign workers. A striking example was the Republic of Austria, which in early May 2020 introduced special lines of direct (night) railway transport through Hungary to allow the arrival of caregivers and other medical per-

14 See: https://ec.europa.eu/info/live-work-travel-eu/health/coronavirus-response/travel-andtransportation-during-coronavirus-pandemic_hr.

15 See: https://www.politico.eu/article/poland-coronavirus-crackdown-on-commuters-hitshealth-and-food-sectors/.

16 Several Croatian and foreign media reported on the protests (for example, https:// www.24sata.hr/news/stotine-su-prosvjedovale-na-njemacko-poljskoj-granici-689384, https://www.nytimes.com/reuters/2020/04/25/world/europe/25reuters-health-coronavirus-cross-border-workers.html). Protests also occurred in the border areas of Poland and the Czech Republic in late April 2020.

17 See: https://www.vecernji.hr/vijesti/njemacka-hitno-uvozi-80-tisuca-sezonaca-za-berbusparoga-i-jagoda-1391461, http://balkans.aljazeera.net/vijesti/njemacka-dovodi-sezonskeradnike. 
sonnel from Romania, while the Austrian borders had already been open to essential workers from neighbouring central European countries. ${ }^{18}$

Migrants, particularly third-country nationals, are more likely to be overrepresented in occupations that are the most affected by COVID-19-related job losses (Sanchez et al., 2020: 7). A significant dismissal of migrant workers, in turn, affects the sources of income of many families in developing countries that depend on remittances. In 2018, developing countries received a total of 529 billion dollars in remittances, while that amount increased to 551 billion dollars in $2019 .{ }^{19}$ Before the pandemic, around 270 million people who lived outside their country of birth sent about 700 billion dollars in remittances to their origin countries. As of mid-May 2020, the 20 countries hardest hit by the COVID-19 outbreak hosted about $55 \%$ of the world's migrants who sent home $54 \%$ of the world's remittances (Moroz, Shrestha and Testaverde, 2020: 2). While remittances generally have a positive effect on developing countries, due to the crisis caused by the transmission of coronavirus, many migrants have lost their jobs and will send less money to their family members. ${ }^{20}$ Approximately one billion people in the world, or every seventh inhabitant of the Earth, is a sender or recipient of remittances. Around eight hundred million people in the world, or every ninth inhabitant, receive such a form of aid from a family member who is a migrant worker. Remittances are most frequently used to meet basic living needs, such as food, medical expenses, education, or housing. Sending remittances to countries of origin has been shown to grow in periods of crisis. ${ }^{21}$ Sending remittances is also more stable than other forms of assistance, such as official development aid to developing countries or private funding. In 2018, the largest number of remittances was sent from the countries most affected by coronavirus (the USA, Switzerland, Germany, Russia, China, France, the Netherlands, and the United Kingdom). Remittances from these countries accounted for more than $25 \%$ of all remittances in 2018. In 2019, $46 \%$ of remittances were sent from the USA, Eurozone countries, the United Kingdom, and Canada to low- and middle-income countries. ${ }^{22}$ The World

18 See: https://euractiv.jutarnji.hr/PiD/zemlje-clanice/austrija-uspostavlja-izravnu-vezuvlakom-za-njegovateljice-iz-rumunjske/10242016/.

19 See: https://www.csis.org/analysis/five-ways-covid-19-changing-global-migration.

20 See: https://www.csis.org/analysis/can-i-stay-or-can-i-go-now-longer-term-impacts-covid-19-global-migration.

21 See: https://news.un.org/en/story/2019/06/1040581.

22 See: https://migrationdataportal.org/themes/migration-data-relevant-covid-19-pandemic. 
Bank had estimated that, in 2020, remittances would be reduced by $20 \%$ compared to 2019, as a consequence of declining income and job losses. ${ }^{23}$

Stricter migration regimes have limited and sometimes even stopped migration in most countries during the first, but also subsequent waves of the COVID-19 pandemic. Following the pandemic, economic migration is likely to intensify and is expected to follow traditional or historical patterns, at least partially. That mostly depends on the speed of economic recovery in the countries that attracted the largest number of migrants, but also on the vaccination campaigns in the countries of origin and destination. However, if borders remain closed for a long time and migrant workers are prevented from regular entry, irregular migration and human trafficking will intensify.

\section{COVID-19 and forced migration}

Already being among the most vulnerable migrant groups and often marginalised within a given society, asylum seekers and refugees are at a greater risk of COVID-19 infection than other migrants. Although they occasionally received media attention due to unregulated border crossings from Bosnia and Herzegovina to Croatia, not much has been elaborated on the COVID-19-related situation and conditions in refugee camps (near the Croatian border, in the $\mathrm{BiH}$ territory) or asylum seeker reception centres in Croatia. However, international organisations responsible for refugee protection, such as the UNHCR and the IOM, are continuously monitoring the situation in refugee camps around the world, proposing measures and making recommendations on how to deal with the development of the pandemic. Along with the institutional and NGO-based efforts in managing pandemic-affected refugees, the response of the academic community has also been recorded. Several studies, both medical and non-medical, address the refugee position during the pandemic in various settlements and contexts, offering longer or shorter analyses, commentaries, and insights (e.g., see Jozaghi and Dahya, 2020 for the Canadian context; Mangrio, Maneesh and Strange, 2020 for Sweden; Salmani, Seddighi and Nikfard, 2020 for Iran; Banik et al., 2020 for Bangladesh).

According to data collected and published by the UNHCR, during the first wave of the pandemic, there were 71 million forcibly displaced persons in

23 See: https://www.worldbank.org/en/news/press-release/2020/04/22/world-bank-predictssharpest-decline-of-remittances-in-recent-history. 
the world, while 134 countries accommodating them reported local transmission of the SARS-CoV-2 virus. ${ }^{24}$ There is general knowledge that diseases do not affect everyone equally, and COVID-19 is no different. As Edmonds and Flahault (2020: 4) stress, "infectious diseases often impact marginalized populations disproportionately, highlighting inequities in access to care and the importance of social determinants of health". According to relevant studies, the vulnerable position of forced migrants is, among other things, reflected in the poor conditions in refugee settlements and camps, but also in other refugee-related spheres. For example, search and rescue operations in the central Mediterranean have been reviewed and suspended due to logistical difficulties caused by COVID-19. This led to more deaths on sea, as well as the immediate quarantining of migrants in reception centres, even though no cases of COVID-19 were confirmed in Africa at that time (Kluge et al., 2020).

The Croatian Institute of Public Health classifies asylum seekers and refugees as a priority group for testing because they are assessed as "persons who, due to their characteristics, have a high potential for infecting a large number of people, with the risk of a rapid spread of infection and cluster formation" ${ }^{25}$ They are included in this group together with prisoners and prison staff, the homeless, and members of ethnic/cultural groups whose lifestyle is conducive to the transmission of the disease by droplets and direct contact. According to the UNHCR, more than $80 \%$ of the world's refugees and almost all internally displaced persons are accommodated in lowand middle-income countries, which creates challenges and specificities in dealing with the COVID-19 pandemic ${ }^{26}$, and reflects the context-dependent effect of the pandemic on refugees and other migrants (Brito, 2020; Gonçalves Júnior et al., 2020). ${ }^{27}$ However, some examples of increased solidarity with this group of migrants do exist ${ }^{28}$ - in Portugal, the best example

24 See: https://www.unhcr.org/coronavirus-covid-19.html.

25 See: https://www.hzjz.hr/priopcenja-mediji/protokol-testiranja-nacovid-19-sars-cov-2/.

26 See: https://www.unhcr.org/coronavirus-covid-19.html.

27 Using the example of migration paths between the Americas, Brito (2020) stresses the importance of the broader geopolitical context differences among migratory groups. He implies that poverty, political instability, natural disasters and violence have shaped migration tendencies in the Americas over the past decade, emphasising the situation of irregular crossings of the southern Mexican border by half a million people every year to seek asylum or to begin the over 1,000-mile journey to the southern US border.

28 See: https://euromedrights.org/publication/access-to-health-for-migrants-and-refugeesduring-covid-19/. 
occurred on 31 March 2020, when the government temporarily granted full civil rights ${ }^{29}$ to all migrants and asylum seekers (for the duration of the COVID-19 epidemic), providing them with access to healthcare and social security. ${ }^{30}$ By amending the Aliens Act, ${ }^{31}$ the Republic of Croatia stipulated that third-country nationals who had been issued residence permits (including those granted permanent residence based on asylum or subsidiary protection), referred to in Article 140, paragraphs 1 and 2 of the Aliens Act, ${ }^{32}$ are not obliged to apply for a new residence permit for the duration of the epidemic caused by the SARS-CoV-2 virus, and for a maximum of thirty days from the date of the declaration of cessation of the epidemic.

In general, refugees face many challenges, some of which are directly related to COVID-19. For example, difficulties in adapting to the new language while trying to obtain reliable information, unhealthy spaces in which refugees live - overcrowded, without access to water, basic sanitation and healthcare facilities, lack of food, lack of human resources due to quarantine and the lack of infrastructure of support agencies in refugee receiving countries (Gonçalves Júnior et al., 2020).

To support an adequate response and recovery-oriented activities relating to COVID-19 in 140 countries, on 15 April 2020, the IOM adopted the Global Strategic Preparedness and Response Plan. ${ }^{33}$ Since the development of a pandemic is defined primarily as a health problem, this strategic plan applies to all types of migration. ${ }^{34}$ The IOM points out that the pandemic has affected spatial mobility very severely, which was described in more detail in the example of labour migration, especially relating to the conditions and regimes for border control and all groups of migrants, including

29 This initiative is in line with recent MIPEX study results, which indicate a high score of Portugal's integration policies ensuring adequate rights and equal opportunities for immigrants in this country (Solano and Huddleston, 2020).

30 See: https://www.jutarnji.hr/vijesti/svijet/treci-su-po-starosti-imaju-najgoru-intenzivnunjegu-u-eu-a-biljeze-cak-pet-puta-manju-smrtnost-od-francuske-kako-je-to-moguce/10241629/, https:/www.schengenvisainfo.com/news/portugal-grants-migrants-andasylum-seekers-full-citizenship-rights-during-covid-19/.

31 See: https://narodne-novine.nn.hr/clanci/sluzbeni/2020_04_53_1059.html.

32 Narodne novine, 130/11, 74/13, 69/17, 46/18, 53/20.

33 See: https://www.iom.int/sites/default/files/defaul/iom_covid19_appeal_15.04.2020.pdf.

34 The IOM's strategy focuses on four priority areas at the national, regional, and community levels: 1) effective coordination and partnerships and mobility tracking, 2) preparedness and response measures for reduced morbidity and mortality, 3) ensuring access to basic services, commodities, and protection to affected persons and 4) mitigating the socio-economic impacts of COVID-19 (https://www.iom.int/sites/default/files/defaul/ iom_covid19_appeal_15.04.2020.pdf). 
those driven by conflict or natural disasters. ${ }^{35}$ It is, therefore, significant to note that the Global Strategic Plan was preceded by a joint statement by the $\mathrm{OHCHR}$, IOM, UNHCR, and WHO on the rights and health of refugees, migrants, and stateless persons in the context of the COVID-19 pandemic. ${ }^{36}$ The statement warns that many refugees and irregular migrants are placed in overcrowded refugee camps, reception centres, and settlements without adequate healthcare and sanitation, particularly pointing to formal and informal detention centres. Therefore, they demand the release of migrant children and their families detained in such centres without a legal basis. A number of scholars and scientists made requests and appeals related to the situation in refugee camps affecting basic human rights and leading to a possible humanitarian crisis (Vonen et al., 2020; San Lau, 2020). Further on, the statement also advocates an inclusive approach that protects every individual's rights to life and health, including refugees and irregular migrants. Authorities must safeguard these rights and ensure equal access to all healthcare services, as well as inclusion in national measures against the COVID-19 pandemic to avoid a disaster. In other words, as Edmonds and Flahault (2020: 4) emphasise, "individual health security measures ensuring access to a strong healthcare system for the entire population are critical for success in public health, especially within the context of a pandemic. The provision of quality healthcare for all provides a level of security for all, not just the ones in need". Finally, the joint statement reflects on border management mechanisms, i.e., border closure and restriction of crossings, urging the states to manage borders in a manner that respects international human rights and refugee protection standards, including the principle of non-refoulement, through health checks and quarantine.

Except for the limited access to healthcare and poor living conditions, some other aggravating circumstances affect refugees in the context of disease development. Based on the literature review, Edmonds and Flahault (2020) single out the following ones: health insurance, health literacy, access to personal protective equipment and testing capacity, economic measures, closure of public spaces - especially schools, community and religious centres, and closure of borders.

According to available information, during the first wave of the pandemic, no cases of SARS-CoV-2 infection were recorded among asylum seekers in

35 See: https://www.iom.int/covid19.

36 See: https://www.iom.int/news/rights-and-health-refugees-migrants-and-stateless-mustbe-protected-covid-19-response. 
the Republic of Croatia, and the Porin Reception Centre for International Protection Seekers introduced pandemic measures. ${ }^{37}$ Within the STIRE project, which intends to support the integration of persons in need of international protection, asylum seekers, and refugees, information on measures relating to the COVID-19 pandemic in Croatia was made available in English. The protection instructions in the reception centre were translated into the asylum seekers' languages ${ }^{38}$ with the help of the Croatian Red Cross. Signs were placed at the premises to ensure the prescribed spatial distance between the residents. However, staff from the Centre for Peace Studies (CMS) warned that the already substandard accommodation conditions in existing facilities for asylum seekers were inadequate to enable self-isolation, which poses an additional health risk and encourages panic among residents. ${ }^{39}$ As pointed out by one of the CMS employees, most organisations dealing with the protection of the rights of asylum seekers and refugees in Croatia could not access the Porin shelter. The Croatian Red Cross provided asylum-seekers with essential services and sanitary supplies, while the organisation Doctors of the World ensured health surveillance and support. ${ }^{40}$

During the first wave of the pandemic, the process of accepting refugees as part of the European resettlement programme was suspended in Croatia. After it was announced in early March 2020 that Croatia was willing to accept part of the children living under inhumane conditions in refugee camps on the Greek islands, the decision was postponed until further notice due to the COVID-19 pandemic and the earthquake in Zagreb. ${ }^{41}$

Newly expected insecurities for refugees and other forced and irregular migrants refer to the further control of the disease by vaccination. Based on the evidence showing how asylum seekers, refugees and foreign-born migrants have been treated during national lockdowns, there is little chance that this population will be considered for immunisation when the vaccine reaches the borders of various countries (Mukumbang, 2020). Further on,

37 See: http://www.maz.hr/2020/04/22/sara-kekus-tijekom-pandemije-nuzno-je-zastititi-najranjivije-skupine/.

38 See: https://stire.org/croatia/health/.

39 See: http://www.novilist.hr/Vijesti/Svijet/Kako-ih-staviti-u-samoizolaciju-Pandemija-koronavirusa-problem-ilegalnih-migranata-ucinila-jos-gorim.

40 See: http://www.maz.hr/2020/04/22/sara-kekus-tijekom-pandemije-nuzno-je-zastititi-najranjivije-skupine/.

41 See: https://www.telegram.hr/politika-kriminal/doznajemo-hrvatska-odgodila-prihvatdjece-izbjeglica/. 
Reidy (2020) warns that "some governments are likely to take advantage of the COVID-19 crisis to push through legally dubious, hardline migration policies that cannot be justified by public health concerns. The glaring absence of migration-aware and mobility-competent policies is likely going to reduce the level of engagement of asylum seekers, refugees and foreign migrants in the national fight against the COVID-19 pandemic and thus reducing their consideration for a COVID-19 vaccine" (Mukumbang, 2020: 2).

\section{Xenophobia, discrimination, and nationalism in the context of COVID-19 pandemic}

The simultaneous pressures caused by mass migration, the COVID-19 pandemic, and epidemiological measures have multiplied the questions about the relationship of receiving societies to immigrants. One can assume that, in a given society, this relationship would not differ significantly in terms of values before and after the pandemic crisis. However, this simple assumption does not exclude the possibility of nuanced responses to multiple social crises caused by these processes in particular societies. They are associated with a number of factors specific to these societies, some of them dating back to the past and others relating to contemporary events.

Dennison and Geddes (2020) do not assume that the new coronavirus pandemic will necessarily cause more negative attitudes toward immigrants. They base their argument on the general trend of a gradual increase in more positive or at least less negative attitudes toward immigrants in the 21st century in European, primarily traditional immigration countries, as well as the assumption that health and economic problems will overshadow immigration as a source of problems. ${ }^{42}$ The latter proved to be a good prediction because the results of the latest Eurobarometer survey (EU, 2020b) show that EU citizens consider their countries are facing primarily economic and health problems, while immigration fell from fifth to seventh place on the list of problems in the period from autumn 2019 to summer 2020. It is difficult to say that the conclusions of Dennison and Geddes (2020) on the attitude towards immigrants are refuted by the results of the last Eurobarometer survey since they indicate only a small shift of $1 \%$ compared to the

42 Dennison and Geddes (2020) refer to pan-European research studies such as the European Social Survey (ESS), which monitors changes in attitudes towards immigrants since 2002 and shows that from 2014 (to 2018), these changes were positive in most European countries. In some countries, such as Hungary, Poland, Italy, and Austria, where there is no such positive shift, the authors conclude that at least the negative attitudes are somewhat weaker. 
previous survey cycle. However, it should be noted that they show a slight decline in positive and a weak increase in negative feelings when it comes to the perception of immigration at the EU level, regardless of the direction of movement - from EU countries to a particular member state or from outside the EU (EU, 2020a). ${ }^{43}$ Besides, one could say that the characteristic indicator is the number of European Union countries in which these changes can be observed. Thus, for example, from spring 2018 to autumn 2019, an increase in positive feelings related to the perception of immigrants from non-EU countries was recorded in 24 out of the 28 EU member states, while in the same number of countries, a decrease in negative feelings was recorded. In the period from autumn 2019 to summer 2020, these numbers almost halved, so an increase in positive feelings was recorded in 11 countries (among 27), and a decrease in negative feelings in 12. These changes suggest that the pandemic and complete or partial closure of the borders did not completely cover the visibility of the immigration issue, so it seems possible to expect a difference in the level of the emotional charge of prejudiced attitudes and their prevalence in the population. According to the experience from similar historical situations (White, 2020) and conclusions within migration theories, they will not change in favour of immigrants. White (2020) emphasises several examples of xenophobic and racist responses to the epidemic risk throughout history, which he believes were regularly linked to economic growth and trade, and which have affected the relation towards people of non-European descent and their mobility. Even before the COVID-19 pandemic, migration research had shown that migrants are also seen as a health threat (see, e.g., Župarić-Iljić and Gregurović, 2013). However, one should note that most pre-pandemic research showed that the perception of immigration as a symbolic (cultural) threat is much stronger than the perception of immigration as a realistic threat (cf. McLaren, 2003; Sides

43 The latest Eurobarometer survey (EU, 2020a) showed that the decline in positive and the increase in negative feelings towards immigration is more noticeable when it comes to feelings towards immigration from countries outside the European Union. More than half of the citizens in most EU member states (17 out of 27 ) have negative feelings about their possibility of immigration. For Croatia, scholarly research has shown that, among the local population, xenophobic attitudes can be identified within a strong sense of threat posed by immigration and are more or less supported by socio-demographic and contextual factors (see Čačić-Kumpes, Gregurović and Kumpes, 2012). However, the results of the latest Eurobarometer survey suggest a kind of positive shift. In that survey, Croatian citizens ranked among countries such as Ireland, Spain, Luxembourg, the Netherlands, Portugal, Romania and Sweden, where more than half of respondents (between 52 and $70 \%$ ) have positive feelings about the immigration of persons originating outside the EU. In Croatia, $50 \%$ of respondents expressing positive feelings, compared to $45 \%$ of those with negative ones (EU, 2020a). 
and Citrin, 2007). Therefore, an increase in xenophobia, discrimination, and nationalism is probably expected together with a decline in already low solidarity with immigrants, and especially with asylum seekers and refugees in the context of almost suspended migration policies, for example, in the European Union. After all, precisely those social problems accumulating as a consequence of the pandemic, and which the EU citizens perceived as problems faced by their countries (as the Eurobarometer survey (EU, 2020b) has shown), are fertile ground for anti-immigrant attitudes.

Even though immigration and immigration issues have been suppressed by health issues, epidemiological measures and, consequently, economybased problems, the possibility of instrumentalisation anti-immigrant attitudes for political purposes has not disappeared. This possibility is occurring despite the complete or partial closure of state borders, the maximum reduction of the entire functioning within the national state and the fear of the "invisible little intruder", which somewhat suppressed the need for ritual populist right-wing intimidation by migrant "intruders". Some governments did not hesitate to impose additional epidemiological measures after the borders were closed to all, including immigrants. ${ }^{44}$ Demands for solidarity with those awaiting entry and who had already found themselves in certain countries were expressed mainly by the civil sector (Mazzola and Martiniello, 2020). ${ }^{45}$ In Croatia, too, the civil sector is almost alone in issuing continuous warnings of the need for solidarity with migrants as one of the most vulnerable groups. Amidst closed borders and sporadic mention of migrants in the public space, while the Croatian authorities are trying to prevent the entry of irregular migrants, civil and humanitarian organisations, both Croatian and international, have criticised them for ruthlessness. They have demanded comments on repeated reports of inhumane behaviour the police exhibit towards migrants attempting to enter the EU across the Croatian border, which in turn seeks to become part of the Schengen Area. ${ }^{46}$

The isolationism enabled by the epidemiological measures has manifested itself in the need to protect state borders, especially the external borders of the European Union. It has actively reduced solidarity with immigrants

44 For example, Belgian and German authorities issued decisions not to accept asylum applications (see Mazzola and Martiniello, 2020).

45 Only Portugal formally and officially supported the principle of solidarity with immigrants (Guadagno, 2020; Mazzola and Martiniello, 2020).

46 See: http://welcome.cms.hr/index.php/2020/05/22/inicijativa-dobrodosli-od-ministarstvaunutarnjih-poslova-trazi-ucinkovitu-istragu-nasilja-nad-izbjeglicama/. 
and, in some cases, became an excuse for xenophobic behaviour. According to the IOM, on the one hand, the isolation of migrants in the newly opened camp in Bosnia and Herzegovina near the Croatian border is justified as an emergency measure to prevent the spread of COVID-19 and on the other, the Hungarian Prime Minister Viktor Orbán used the same argument to ban entry and passage through Hungary (Guadagno, 2020). In this sense, among others, Mazzola and Martiniello (2020) point out that the far-right does not miss the opportunity to remind of the danger posed by immigrants. However, the collective fear caused by the pandemic is not fuelled only by the far-right opponents, as the authors indicate is the case in Greece. The same xenophobic rhetoric was used by those in power, such as Prime Minister Viktor Orbán in Hungary and former President Donald Trump in America.

Statements and policies by right-wing populists, such as former Italian Minister of the Interior Matteo Salvini, who called for border closure based on a false implication of a causal relationship between the epidemic and African asylum seekers, and Donald Trump, who referred to the new coronavirus as a "Chinese virus" (Devakumar et al., 2020), are not isolated exceptions. Therefore, it is not difficult to presume that the accumulated pressure and fear of the spread of the infection will fuel nationalist egoism, which was already exhibited during pre-coronavirus times through anti-immigration rhetoric and xenophobic attitudes. The xenophobophile rhetoric has taken over the European political space to such an extent that it has become accepted by the public as a regular pre-election occurrence, a powerful populist means of gaining power, winning referendums, and the like. (see, e.g., Understanding Pegida in Context, 2015; Bauman, 2016; Gow and Meyer, 2016; cf. Kumpes, 2018). The fear of infection and economic insecurity additionally exacerbate the flourishing of the already pervasive xenophobia and Islamophobia in the context of the occurrence of specific cultural racism when dealing with the attitudes towards immigrants (cf. Pavelić and ČačićKumpes, 2015; Pickel and Öztürk, 2018). Vertovec (2020) warns that it is already clear that the coronavirus pandemic is fuelling xenophobia and racism worldwide directed at the presumed carriers of the disease. In France, for example, the popular hashtag \#JeNeSuisPasUnVirus (I am not a virus) has been used among French people of Asian descent to express their frustration over the stigma and discrimination associated with the epidemic. ${ }^{47}$

47 See: https://www.euronews.com/2020/02/03/coronavirus-france-faces-epidemic-of-antiasian-racism. 
Sinophobic outbursts have been reported worldwide; in China, neighbouring Asian countries, western European countries, the United States, ${ }^{48}$ and even Croatia. ${ }^{49}$ In most of these countries, these outbursts are a matter of a close link between xenophobia and racism because even non-Chinese Asians or those of Chinese origin were stigmatised and physically attacked due to real or feigned fears of the "Chinese virus". In this regard, White (2020: 2) recalls that attacks on people of Asian descent related to COVID-19 are a legacy of the long-standing association of the health threat with the movement of Asians. In such situations, as Vertovec (2020) warns, the fear and hatred that is sometimes directed at special groups are often generalised to larger groups, migrants, be they economic migrants, refugees, or asylum seekers.

As stated in the IOM's analytical snapshot on migrant stigmatisation and discrimination, the virus itself does not discriminate in its transmission, but "the pandemic has exacerbated pre-existing social and economic disparities, with migrants among the groups facing the additional burdens of stigmatization and discrimination" (IOM, 2020b: 1). Besides being victims of xenophobic attacks and discrimination, they are easier targets for infection due to more exposure to adverse living conditions (hunger, job and employment insecurity, disproportionately more frequent housing in unfavourable conditions and polluted environment, and return migration) (IOM, 2020b: 1). Much has been said about the COVID-19 pandemic as a biological and emotional trauma, but as Alexander (2020) warns, it can also be a social trauma "challenging the collective identity that anchors a group's cultural security". Pandemic management will leave a mark in the social, political, economic, and cultural fields around the world, and the consequences of the trauma will affect each country, as primarily indebted for the pandemic management, as well as supranational entities, such as the EU. For many reasons, the cultural trauma caused by the pandemic and its management will require a revision of the image that individual countries and the EU as a whole have of themselves. One aspect of this revision will need to be linked to migration narratives. Migration is an important part of European

48 See: https://www.euronews.com/2020/03/05/covid-19-and-xenophobia-why-outbreaksare-often-accompanied-by-racism.

49 Verbal and physical attacks against tourists took place in Croatia, as warned by the Ombudswoman (https://www.ombudsman.hr/hr/stigmatizacija-moze-dovesti-do-krsenjaprava-diskriminacije-ali-i-umanjiti-napore-suzbijanja-epidemije/), as well as against an athlete of Chinese origin (https://www.jutarnji.hr/vijesti/hrvatska/sramotni-ispad-navijaca-dubrovackog-kluba-vrijedali-hrvatskog-stolnotenisaca-kineskog-podrijetla-sad-cetata-odraditi-peti-mec-protiv-koronavirusa/9986719/). 
everyday life, and the narratives about it, as can be derived from this rough sketch, are strongly connected with revived or strengthened nationalisms, xenophobia and discrimination, as well as questionable internal solidarity and solidarity with refugees, asylum seekers and migrants as a whole.

\section{CONCLUSIONS}

Different measures have been imposed throughout history to control and prevent the transmission of infectious diseases, depending on the type of infection, its prevalence, socio-economic conditions in a particular area, and the development of medicine. Among the measures most frequently resorted to in the event of epidemics, restricting the spatial mobility of people has remained the most effective to date, regardless of its side effects. With the establishment of early modern European states, public healthcare emerged as a response of national institutions to the outbreaks of highly infectious diseases. Since then, balancing between medical and economic interests has been carefully chosen as a strategy within public health policies - primarily to prevent the spread of disease while maintaining economic sustainability. One of the longest-lasting European anti-epidemic systems was established during the 18th century in the Croatian territory. It was the forerunner of the modern public health system in Croatia.

Aside from dealing with the new coronavirus pandemic, the EU tends to coordinate the functioning of national healthcare systems. However, the EU clearly cannot make effective recommendations on combating the infection that would be equally applicable to all member states due to different sociodemographic circumstances and healthcare needs which were even more accentuated during the first wave of the COVID-19 pandemic. Therefore, in the general social context of imposing restrictions and even closing borders, some EU member states resort to different solutions, weighing between economic necessity and concern for the health of national populations, at least on a declarative level. Each of the public health measures for the prevention of epidemics introduced from the early Middle Ages up to the present affected even the small, isolated communities, let alone large, complex, and highly interconnected economic systems.

The COVID-19 outbreak has triggered border closures around the world, including the Schengen area, to prevent transmission of the SARS-CoV-2 virus. The vision of borderless Europe has been suspended by re-establishing and strengthening border controls, consequently preventing European citi- 
zens from free movement. The greatest achievement of the EU integration policy, which allowed free movement of European citizens in the Schengen area, has been jeopardised. Re-establishing border guards and re-introducing border infrastructure that had not existed for decades are posing new challenges for border management in the EU member states.

Dependence on migration, i.e., the spatial mobility of the labour force, is one of the main descriptors of both today's global economy and individual national economies. Migrant-employing sectors such as agriculture, tourism and hospitality have been heavily affected by the pandemic, including migrants themselves and their families as direct victims suffering serious financial consequences due to the significant dismissal and job losses.

Along with the regular labour migrants, specific categories of the population in terms of age (i.e., people aged 65 and over) and other types of migrants (asylum seekers, refugees, forcibly displaced persons, and stateless persons) are particularly vulnerable due to exposure to the virus and possible more severe consequences of the disease. Individual health security measures ensuring access to a strong healthcare system for the entire population are critical for maintaining public health, especially within the context of a pandemic. The provision of quality healthcare for all provides a level of security for all, not just the ones in need.

Finally, the restrictions imposed during the first wave of the pandemic are likely to hold on in some form for a longer period, due to fears of virus transmission, transport constraints, political reasons, but also xenophobia. Today's globalised world, relying on human mobility and migrant work, will have to face the consequences of limited labour supply on which many sectors in economically developed countries depend, as well as other consequences of reduced mobility, such as legally pushing through hard-line migration policies under the guise of public health concern. An increase in xenophobia, discrimination, and nationalism is probably expected, together with a decline in already low solidarity with immigrants, and especially with asylum seekers and refugees in the context of almost suspended migration policies and possible systems of vaccine administration, which may lead to withholding or hampering access to vaccine for some groups. Serving as an example, national leaders now, as they have done throughout history, promote vaccination as an efficient anti-epidemic method. However, the issues of vaccination are becoming a new battlefield in the already established (and functioning) systems of pandemic management. 


\section{REFERENCES}

Alexander, J. C. (2020). The Double Whammy Trauma: Narrative and CounterNarrative during Covid-Floyd, Thesis Eleven, https://thesiseleven.com/2020/07/09/ the-double-whammy-trauma-narrative-and-counter-narrative-during-covid-floyd/ (12 September 2020).

Banik, R., Rahman, M., Hossain, M., Sikder, T. and Gozal, D. (2020). COVID-19 pandemic and Rohingya refugees in Bangladesh: What are the major concerns?, Global Public Health, 15 (10): 1578-1581. https://doi.org/10.1080/17441692.2020.1812103

Bauman, Z. (2016). Strangers at Our Door. Cambridge: Polity Press.

Bell, M. and Ward, G. (2000). Comparing temporary mobility with permanent migration, Tourism Geographies, 2 (1): 87-107. https://doiorg/10.1080/146166800363466

Borjas, G. J. and Cassidy, H. (2020). The Adverse Effect of the COVID-19 labor Market Shock on Immigrant Employment. Bonn: IZA Institute of Labor Economics (IZA Discussion Paper, 13277), http://ftp.iza.org/dp13277.pdf (17 September 2020).

Božić-Bužančić, D. (1990). Liječenje kuge u Dalmaciji u XVIII. stoljeću, Radovi Zavoda za hrvatsku povijest, 23: 247-257.

Brito, M. O. (2020). COVID-19 in the Americas: Who's Looking After Refugees and Migrants?, Annals of Global Health, 86 (1). https://doi.org/10.5334/aogh.2915

Buklijaš, T. (2002). Kuga: nastajanje identiteta bolesti, Hrvatska revija, 2 (2): 90-94.

Čačić-Kumpes, J., Gregurović, S. and Kumpes, J. (2012). Migracija, integracija i stavovi prema imigrantima u Hrvatskoj, Revija za sociologiju, 42 (3): 305-336. https://doi. org/10.5613/rzs.42.3.3

Conrad, C. (2001). Social History, in: International Encyclopedia of the Social \& Behavioral Sciences. Amsterdam - Oxford: Elsevier, 14299-14306.

[Delumeau, J.] Delimo, Ž. (1987). Strah na zapadu (od XIV do XVIII veka): opsednuti grad, I-II. Novi Sad: Dnevnik - Književna zajednica Novog Sada.

Dennison, J. and Geddes, A. (2020). Why COVID-19 does not necessarily mean that attitudes towards immigration will become more negative. Geneva: IOM, https:// publications.iom.int/system/files/pdf/why-covid19.pdf (20 September 2020).

Devakumar, D., Shannon, G., Bhopal, S. S. and Abubakar, I. (2020). Racism and discrimination in COVID-19 responses, The Lancet, 395 (10231): 1194. https://doi. org/10.1016/S0140-6736(20)30792-3

Edmonds, J. and Flahault, A. (2021). Refugees in Canada during the FirstWave of the COVID-19 Pandemic, International Journal of Environmental Research and Public Health, 18 (947). https://doi.org/10.3390/ijerph18030947

[Engel, F. Š.] Енгел, Ф. Ш. (2003). [Opis Kraljevine Slavonije i Vojvodstva Srema] Onuc Кралевине Славоније и Војводства Срема. [Novi Sad: Matica srpska] Нови Сад: Матица српска.

EU (2020a). Europeans' opinions about the European Union's priorities: Report (Standard Eurobarometer 93: Summer 2020). European Union, Directorate-General for Communication.

EU (2020b). Public opinion in the European Union: Report (Standard Eurobarometer 93: Summer 2020). European Union, Directorate-General for Communication. 
Fasani, F. and Mazza, J. (2020). A Vulnerable Workforce: Migrant Workers in the COVID-19 Pandemic. Luxembourg: Publications Office of the European Union. https://doi. org/10.2760/316665

Fasani, F. and Mazza, J. (2021). COVID-19 and migrant workers' employment prospects in Europe, VoxEU.org, CEPR's policy portal, 25 January 2021, https://voxeu.org/ article/covid-19-and-migrant-workers-employment-prospects-europe (3 February 2021).

Gelatt, J. (2020). Immigrant Workers: Vital to the U.S. COVID-19 Response, Disproportionately Vulnerable. Washington: Migration Policy Institute (MPI), https://www.migration policy.org/research/immigrant-workers-us-covid-19-response (20 May 2020).

Glesinger, L. (1954). Medicina kroz vjekove. Zagreb: Zora.

Gow, D. and Meyer, H. (eds) [2016]. Brexit: The Politics of a Bad Idea. London: FriedrichEbert-Stiftung - Social Europe (https://www.socialeurope.eu/wp-content/uploads /2016/05/Brexit-The-Politics-of-a-Bad-Idea.pdf).

Grmek, M. D. (1989). Bolesti u osvit zapadne civilizacije. Zagreb: Globus.

Guadagno, L. (2020). Migrants and the COVID-19 pandemic: An initial analysis. Geneva: International Organization for Migration (Migration Research Series, 60).

Heršak, E. (ed.) (1998). Leksikon migracijskoga i etničkoga nazivlja. Zagreb: IMIN - Školska knjiga.

Horbec, I. (2015). Zdravlje naroda bogatstvo države. Prosvijećeni apsolutizam i počeci sustava javnoga zdravstva u Hrvatskoj. Zagreb: Hrvatski institut za povijest.

ILO (2018). ILO Global Estimates on International Migrant Workers: Results and Methodology, 2nd ed. Geneva, https://www.ilo.org/wcmsp5/groups/public/---dgreports/---dcomm /---publ/documents/publication/wcms_652001.pdf (11 April 2020).

IOM (2020a). World Migration Report 2020. Geneva, https://publications.iom.int/system/ files/pdf/wmr_2020.pdf (17 September 2020).

IOM (2020b). COVID-19 Analytical Snapshot \#29: Stigmatization and Discrimination UPDATE. https://www.iom.int/sites/default/files/documents/covid-19_analytical_ snapshot_29_stigmatization_and_discrimination_update.pdf (17 May 2020).

Jozaghi, E. and Dahya, A. (2020). Refugees, asylum seekers and COVID-19: Canada needs to do more to protect at-risk refugees during the current pandemic, Canadian Journal of Public Health, (111): 413-414. https://doi.org/10.17269/s41997-020-00357-8

Jucier Gonçalves Júnior, J., de Sales, J. P., Moreno Moreira, M., Rodrigues Pinheiro, W., Tavares Lima, C. K. and Rolim Neto, M. L. (2020). A crisis within the crisis: The mental health situation of refugees in the world during the 2019 coronavirus (2019-nCoV) outbreak, Psychiatry Research, 288. https://doi.org/10.1016/j.psychres.2020.113000

Kečkemet, D. (1975). Prilozi opisu i povijesti splitskog lazareta, Pomorski zbornik, 13: 377-403.

Klueting, H. (2007). Das konfessionelle Zeitalter. Europa zwischen Mittelalter und Moderne. Darmstadt: Primus Verlag.

Kluge, H. H., Jakab, Z., Bartovic, J., D'Anna, V. and Severoni, S. (2020). Refugee and migrant health in the COVID-19 response, Lancet, 395. https://doi.org/10.1016/S01406736(20)30791-1

Kolanović, J. (1995). Šibenik u kasnome srednjem vijeku. Zagreb: Školska knjiga.

Kumpes, J. (2018). Religioznost i stavovi prema imigrantima u Hrvatskoj, Migracijske $i$ etničke teme, 34 (3): 275-320. https://doi.org/10.11567/met.34.3.3 
Livi Bacci, M. (2000). The Population of Europe. Oxford - Malden: Blackwell Publishers.

Mangrio, E., Maneesh P.-S. and Strange, M. (2020). Refugees in Sweden During the Covid-19 Pandemic - The Need for a New Perspective on Health and Integration, Frontiers in Public Health, 8: 574334. https://doi.org/10.3389/fpubh.2020.574334

Mazzola, A. and Martiniello, M. (2020). Le Covid-19 brise les fragiles solidarités avec les réfugiés, The Conversation, 1 April, 2020, https://theconversation.com/le-covid-19brise-les-fragiles-solidarites-avec-les-refugies-134737 (17 May 2020).

McLaren, L. M. (2003). Anti-Immigrant Prejudice in Europe: Contact, Threat Perception, and Preferences for the Exclusion of Migrants, Social Forces, 81 (3): 909-936. https:// doi.org/10.1353/sof.2003.0038

Moroz, H., Shrestha, M. and Testaverde, M. (2020). Potential Responses to the COVID-19 Outbreak in Support of Migrant Workers. Washington, DC: World Bank, https:// openknowledge.worldbank.org/handle/10986/33625 (21 September 2020).

Mukumbang, F. C. (2020). Are asylum seekers, refugees and foreign migrants considered in the COVID-19 vaccine discourse?, BMJ Global Health, 2020 (5): e 004085. https://doi. org/10.1136/bmigh-2020-004085

OECD/ILO (2018). How Immigrants Contribute to Developing Countries' Economies. Paris: OECD Publishing. https://doi.org/10.1787/9789264288737-en

Paul, R. (2020). Europe's essential workers: Migration and pandemic politics in Central and Eastern Europe during COVID-19, European Policy Analysis, 2020 (6): 238-263. https://doi.org/10.1002/epa2.1105

Pavelić, A. and Čačić-Kumpes, J. (2015). Islam, islamofobija i Zapad: suprotstavljeni pogledi i društvena stvarnost, Migracijske i etničke teme, 31 (3): 407-427. https://doi. org/10.11567/met.31.3.4

Peričić, Š. (1974). Zadranin Grgur Stratico (1736. - 1806.), Radovi Centra JAZU u Zadru, 21: 271-289.

Pickel, G. and Öztürk, C. (2018). Islamophobia Without Muslims? The "Contact Hypothesis" as an Explanation for Anti-Muslim Attitudes - Eastern European Societies in a Comparative Perspective, Journal of Nationalism, Memory \& Language Politics, 12 (2): 162-191. https://doi.org/10.2478/jnmlp-2018-0009

Ravančić, G. (2010). Vrijeme umiranja - Crna smrt u Dubrovniku 1348. - 1349. Zagreb: Hrvatski institut za povijest.

Reidy, E. (2020). The COVID-19 excuse? How migration policies are hardening around the globe, The New Humanitarian, 17 April, 2020, https://www.thenewhumanitarian.org/ analysis/2020/04/17/coronavirus-global-migration-policies-exploited (17 May 2020).

Salmani, I., Seddighi, H. and Nikfard, M. (2020). Access to Health Care Services for Afghan Refugees in Iran in the COVID-19 Pandemic, Disaster Medicine and Public Health Preparedness, 14 (4). https://doi.org/10.1017/dmp.2020.240

San Lau, L., Samari, G., Moresky, R. T., Casey, S. E., Kachur, P., Roberts, L. F. and Zard, M. (2020). COVID-19 in humanitarian settings and lessons learned from past epidemics, Nature Medicine, (26): 640-648. https://doi.org/10.1038/s41591-020-0851-2

Sanchez, D. G., Parra, N., Ozden, C. and Rijkers, B. (2020). Which jobs are most vulnerable to COVID-19? What an analysis of the European Union reveals. Washington: World Bank (Research and policy briefs from the World Bank Malaysia Hub, 34), http://documents. worldbank.org/curated/en/820351589209840894/Which-Jobs-Are-Most-Vulnerable-toCOVID-19-What-an-Analysis-of-the-European-Union-Reveals (17 September 2020). 
Sides, J. and Citrin, J. (2007). European Opinion About Immigration: The Role of Identities, Interests and Information, British Journal of Political Science, 37 (3): 477-504. https://doi.org/10.1017/s0007123407000257

Skenderović, R. (2015). Sanitarni kordon na Savi i začetci javnog zdravstva u Slavoniji, in: B. Ostajmer (ed.). Rijeka Sava u povijesti: zbornik radova znanstvenog skupa održanog u Slavonskom Brodu. Slavonski Brod: HIP, Podružnica za povijest Slavonije, Srijema i Baranje, 315-327.

Snowden, M. F. (2019). Epidemics and Society. From Black Death to the Present. New Haven - London: Yale University Press.

Solano, G. and Huddleston, T. (2020). Migrant Integration Policy Index 2020. Barcelona Brussels: CIDOB - MPG.

Swann, J. (2000). Politics and the state in eighteenth-century Europe, in: T. C. W. Blanning (ed.). The Eighteenth Century. Europe 1688-1815. Oxford: Oxford University Press, 11-51.

Tartalja, H. (1979). Turske karantenske odredbe, Pomorski zbornik, 17: 435-446.

Taube, F. W. von (2012). Povijesni i zemljopisni opis Kraljevine Slavonije i Vojvodstva Srijema. Osijek: Državni arhiv u Osijeku.

Thießen, M. (2015). Infizierte Gesellschaften: Sozial- und Kulturgeschichte von Seuchen, APuZ - Aus Politik und Zeitgeschichte (Beilage zur Wochenzeitung Das Parlament), 65 (20-21): 11-18.

Understanding Pegida in Context (2015). London: Social Europe - Friedrich-Ebert-Stiftung, https://www.socialeurope.eu/focus/understanding-pegida-in-context (11 April 2020).

Vaniček, F. (1875). Specialgeschichte der Militärgrenze aus Originalquellen und Quellenwerken geschöpft, vol. I-IV. Wien: Kaiserlich-königliche Hof- und Staatsdruckerei.

Vertovec, S. (2020). Covid-19 and enduring stigma: The corona pandemic increases xenophobia and exclusion worldwide, Max-Planck-Gesellschaft, 27 April, 2020, https://www.mpg.de/14741776/covid-19-and-enduring-stigma?c=14642203 (21 May 2020).

Vonen, H. D., Olsen, M. L., Eriksen, S. S., Jervelund, S. S. and Eikemo, T. A. (2021). Refugee camps and COVID-19: Can we prevent a humanitarian crisis?, Scandinavian Journal of Public Health, 49 (1): 27-28. https://doi.org/10.1177/1403494820934952

White, A. I. R. (2020). Historical linkages: epidemic threat, economic risk, and xenophobia, The Lancet, 395 (10232): 1250-1251. https://doi.org/10.1016/S0140-6736(20)30737-6

WHO (2020). ApartTogether survey: preliminary overview of refugees and migrants selfreported impact of COVID-19. Geneva: World Health Organization.

Wiesböck, L., Reinprecht, C., Haindorfer, R. and Verwiebe, R. (2016). Cross-Border Commuting and Transformational Dynamics in Europe: What Is the Link?, in: A. Amelina, K. Horvath and B. Meeus (eds). An Anthology of Migration and Social Transformation: European Perspectives. Cham: Springer, 187-200. https://doi.org/ 10.1007/978-3-319-23666-7_12

Župarić-Iljić, D. and Gregurović, M. (2013). Stavovi studenata prema tražiteljima azila u Republici Hrvatskoj, Društvena istraživanja, 22 (1): 41-62. https://doi.org/10.5559/ di.22.1.03 


\title{
SOURCES
}

Croatian State Archives

Hrvatska - Hrvatski državni arhiv, Zagreb - fond 430 - Slavonska generalkomanda (HR-HDA-430-SGK)

Hrvatska - Hrvatski državni arhiv, Zagreb - fond 445 - Brodska graničarska pukovnija (HR-HDA-445-BGP)

Hrvatska - Hrvatski državni arhiv, Zagreb - fond 33 - Virovitička županija (HR-HDA33-VŽ)

Scientific Library Zadar

Znanstvena knjižnica Zadar - fond Zbirka rukopisa (ZKZ, Ms.)

State Archives Zadar

Hrvatska - Državni arhiv u Zadru - fond 386 - Zbirka tiskovina/Stampata (HRDAZD-386 Zbirka tiskovina /Stampata)

Hrvatska - Državni arhiv u Zadru - fond 1 - Spisi generalnioh providura (HR-DAZD1-SGP)

\section{Sustavi upravljanja pandemijom i migracije}

\section{Margareta Gregurović, Snježana Gregurović, Josip Kumpes, Simona Kuti, Sanja Lazanin, Dubravka Mlinarić}

\begin{abstract}
SAŽETAK
Brzi razvoj i širenje bolesti koja predstavlja zdravstvenu prijetnju većem udjelu stanovništva imaju učinak na funkcioniranje gotovo svih društvenih sustava, kako unutar tako i izvan granica nacionalne države, utječući stoga i na mogućnosti slobodnoga kretanja i migracija. Glavni je cilj ovog rada raspraviti osnovne mehanizme kontrole bolesti u odnosu na migracije u različitim društveno-povijesnim kontekstima. Pritom se identificiraju i uspoređuju povijesni obrasci i suvremene mjere sustava preventivne kontrole, uzimajući u obzir širi društveni kontekst i specifični položaj migranata. U ovome se radu kombiniraju povijesni uvidi u različite upravljačke i političke sustave u Europi i Hrvatskoj koji su tražili odgovarajuće mjere za sprečavanje širenja zaraznih bolesti sa stanjem u borbi protiv pandemije bolesti COVID-19. Regulacijom i upravljanjem aktualnom pandemijom bolesti COVID-19 uvedena su ograničenja prekograničnoga kretanja i putovanja. Ta ograničenja i uvođenje karantenskih mjera naglo su zaustavili ne samo međunarodnu već i migraciju unutar granica nacionalnih država, posebno tijekom prvog vala pandemije u proljeće 2020. Stoga je naglasak stavljen na učinke pandemije bolesti COVID-19 na radne i prisilne migracije, ali i na učinak mehanizama upravljanja pandemijom na razvoj stavova javnosti prema imigrantima.
\end{abstract}

KLJUČNE RIJEČI: pandemija, migracije, COVID-19, upravljanje pandemijom, ksenofobija 